\title{
PHYTOPLANKTON COMMUNITY OF A POLYMICTIC RESERVOIR, LA PLATA RIVER BASIN, URUGUAY
}

\author{
PÉREZ, M. C., ${ }^{1}$ BONILLA, S. ${ }^{2}$ and MARTÍNEZ, G. ${ }^{1}$ \\ ${ }^{1}$ Instituto Nacional de Pesca, Departamento de Biología Pesquera, Constituyente 1497, CC 1612, Montevideo, \\ C.P. 11200, Uruguay, e-mail: mcperez@inape.gub.uy \\ ${ }^{2}$ Faculty of Sciences, Sección Limnología, Iguá 4225, CC 10773, Montevideo, \\ C.P. 11400, Uruguay, e-mail: sbon@fcien.edu.uy \\ Correspondence to: Sylvia Bonilla, Faculty of Sciences, Sección Limnología, Iguá 4225, \\ Montevideo, C.P. 11400, Uruguay, e-mail: sbon@fcien.edu.uy \\ Received January 14, 1998 - Accepted February 1, 1999 - Distributed December 22, 1999
}

(With 3 figures)

\begin{abstract}
This paper deals with the analysis of phytoplankton composition and abundance from four sampling stations at the polymictic system, Rincón del Bonete water reservoir in Uruguay. Sampling data were obtained in 4 seasonal periods between February and November 1993. A hundred and twenty-four taxa were identified, where Aulacoseira granulata (Ehrenb.) Simon., A. granulata var. angustissima (Muller) Simon., A. granulata var. angustissima f. spiralis, (Muller) Simon., A. cf. ambigua, (Grun.) Simon., A. cf.. distans (Ehrenb.) Simon., Cryptomonas spp. and Synedra ulna (Nitzsch) Ehrenberg, were always present. Phytoplankton abundance fluctuated between 29 (autumn) and 2129 (summer) $\mathrm{ind} / \mathrm{ml}$. The general dominance of Aulacoseira spp. could be related to the polymictic condition of the system. In cold months phytoplankton distribution was homogeneous among sampling stations, while in warm months, spatial heterogeneity was detected, suggesting that sampling stations can behave as independent compartments.
\end{abstract}

Key words: microalgae, freshwater, artificial lakes, Aulacoseira, Uruguay.

\section{RESUMO}

Comunidade do fitoplâncton em um reservatório polimítico, bacia do Rio de la Plata, Uruguai

Foi realizada uma análise da composição e abundância do fitoplâncton em quatro estações de amostragem em um sistema polimítico, o reservatório do Rincón del Bonete. Os dados amostrais foram obtidos em 4 períodos sazonais, entre fevereiro e novembro de 1993. No total foram registradas 124 taxas, estando Aulacoseira granulata (Ehrenb.) Simon., A. granulata var. angustissima (Muller) Simon., A. granulata var. angustissima f. spiralis (Muller) Simon., A. cf. ambigua (Grun.) Simon., A. cf. distans (Ehrenb.) Simon., Cryptomonas spp. e Synedra ulna (Nitzsch) Ehrenberg, sempre presentes. A abundância do fitoplâncton variou entre 29 e $2129 \mathrm{ind} / \mathrm{ml}$, no outono e verão, respetivamente. A dominância geral do Aulacoseira spp. parece relacionada com a condição polimítica do sistema. No que se refere a composição, a comunidade fitoplanctônica mostrou-se homogênea no inverno. Pórem, nos meses cálidos foi observada heterogeneidade espacial, devido a qual, provavelmente, as estações de coleta estejam comportando-se como subsistemas independentes.

Palavras-chave: microalgae, água doce, reservatórios, Aulacoseira, Uruguai. 


\section{INTRODUCTION}

Reservoirs represent one of the main anthropogenic impacts on the hydrological regime of rivers (Baxter, 1977; Rosenberg et al., 1995). The building of reservoirs for power generation in South America has recently increased (Tundisi, 1994). Specially, the La Plata River basin presents several regions suitable for reservoirs sites (Tundisi, 1990a). In Uruguay, Rincón del Bonete reservoir has been built for power generation on the Negro River, belong to the La Plata River basin.

The modified hydrological cycle due to water use and lake morphometry, could be the main factors controlling the stability of the water column, which in turn influence phytoplankton's structure and dynamics (Tundisi, 1990b; Kölher, 1994). Thus, studies on the phytoplankton community are relevant to manage water quality (Tundisi, 1994). Taxonomic and ecological studies concerning phy- toplankton from reservoirs are scarce in Uruguay (Quirós \& Luchini, 1982; Berón, 1990). The aim of this study was to characterize the phytoplankton species composition and abundance of Rincón del Bonete Reservoir.

\section{MATERIAL AND METHODS}

\section{Study Area}

Rincón del Bonete Reservoir (Fig. 1) was built in 1947 without felling of the riparian forests (Campo, 1991).

The area of the lake is $1,070 \mathrm{Km}^{2}$ with 8,800 $\mathrm{Hm}^{3}$ volume and an average depth of $8.0 \mathrm{~m}$. It is a polymictic system due to the morphometric features, the wind effect and the artificial management (Conde et al., 1994). The climate of the region is temperate (mean air temperature: 23 and $12^{\circ} \mathrm{C}$, in summer and winter, respectively), with irregular rainfall along the year (annual mean: $1180 \mathrm{~mm}$ ) and

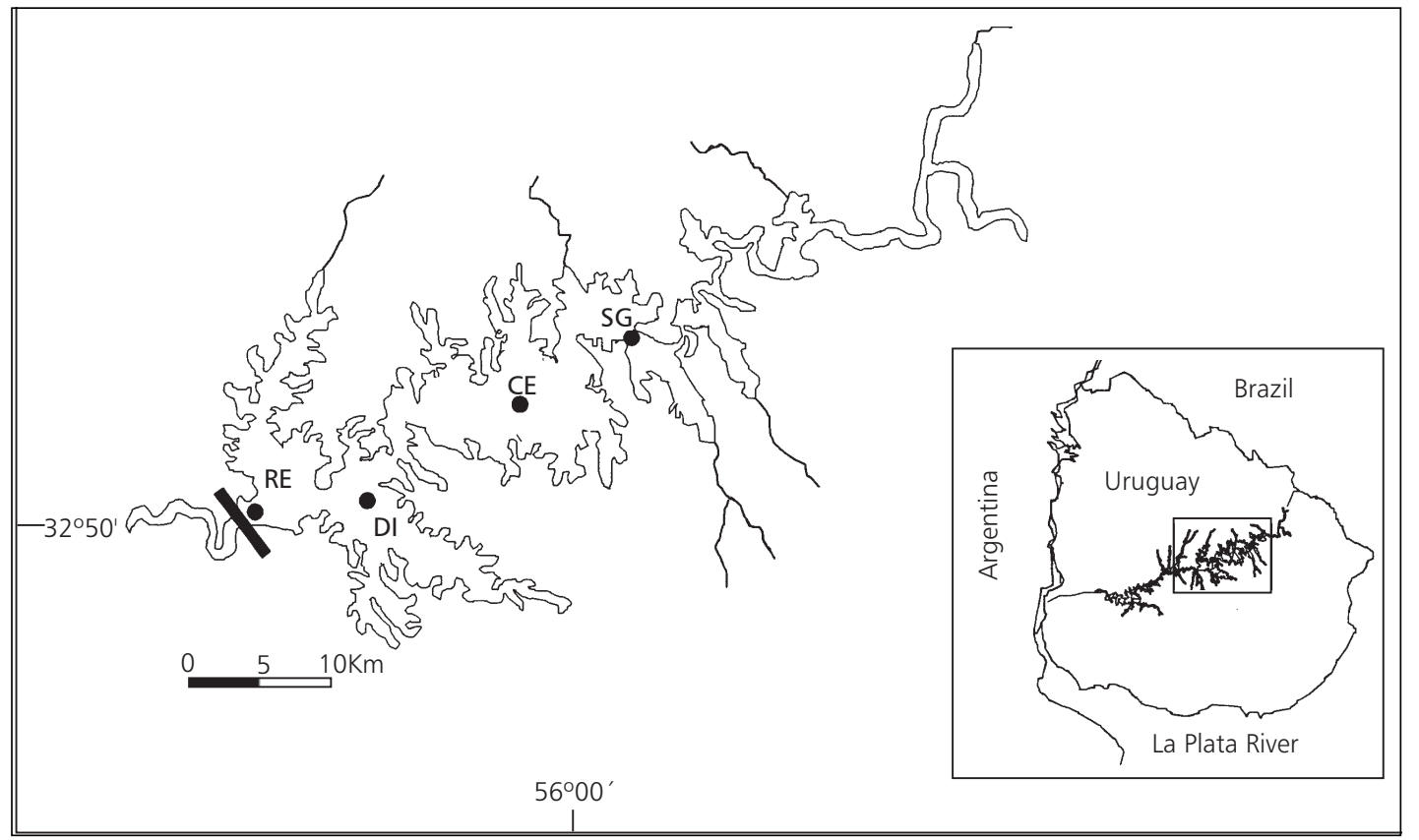

Fig. 1 - Study area showing the four sampling stations at Rincón del Bonete Reservoir. RE: represa, DI: dilfa, CE: centro and SG: San Gregorio. 
an average wind speed of $11 \mathrm{~km} / \mathrm{h}$. No important industries or big cities are located at the basin and the land use is basically cattle raising.

\section{Sampling and analyses}

Samples were taken seasonally in February (summer), May (autumn), July (winter) and November (spring) during 1993, at four stations along the central axis of the artificial lake: Represa (RE), Dilfa (DI), Centro (CE) and San Gregorio (SG) (Fig. 1). Depth, temperature, euphotic zone (Secchi disc), and $\mathrm{pH}$ (pHmeter Basic LCD 2) were measured in situ. Qualitative samples of phytoplankton were taken with a $25 \mu \mathrm{m}$ net, a subsample being immediately preserved with $4 \%$ buffered formaldehyde. It was used the classification system of Bourrelly $(1972,1981,1985)$ to Class level. To identify diatoms, the oxidation technique was followed (Hasle \& Fryxell, 1970).

For quantitative analysis, surface samples of $500 \mathrm{ml}$ were immediately preserved with Lugol's solution. The counting unit was defined according to De Filippo (1987) and Calijuri (1988). Countings were performed following the Utermöhl method (Utermöhl, 1958) and at least 100 individuals of the species or groups more abundant were counted (Lund et al., 1958).

To compare sampling stations, quantitative data of species with an abundance higher than $1 \%$ were used to perform a cluster analysis, using the Euclidean distance and the unweighted pair-group method (Legendre \& Legendre, 1984).

\section{RESULTS}

The deepest station was located near the dam $(15.5-23.0 \mathrm{~m})$ and the shallowest in the upper zone (5.0-6.1 m).

Water temperature presented a seasonal variation at all sampling sites, with maximum values in summer $\left(21-24^{\circ} \mathrm{C}\right)$ and minimum ones in winter $(8-$ $\left.9^{\circ} \mathrm{C}\right)$. Neutral to alcaline $\mathrm{pH}$ values (7.4-8.9) were registered, and in general, highest euphotic zones occurred in summer (Table 1).

TABLE 1

Values of physico-chemical parameters for the four sampling stations at Rincón del Bonete Reservoir.

\begin{tabular}{|l|l|l|l|l|l|}
\hline & \multicolumn{1}{|c|}{ Station } & \multicolumn{1}{|c|}{ Z (m) } & \multicolumn{1}{c|}{ Zeu. $(\mathbf{m})$} & \multicolumn{1}{c|}{ T. $\left({ }^{\circ} \mathbf{C}\right)$} & \multicolumn{1}{c|}{ pH } \\
\hline February & RE & 15.0 & 3.4 & 23 & 8.3 \\
& DI & 12.0 & 2.7 & 21 & 8.9 \\
& CE & 11.0 & 3.0 & 24 & 8.4 \\
& SG & 5.0 & 1.1 & 22 & 7.8 \\
\hline May & RE & 16.0 & 1.9 & 15 & 8.3 \\
& DI & 11.0 & 1.4 & 14 & 8.4 \\
& CE & 10.0 & 0.9 & 16 & 8.4 \\
& SG & 6.0 & 1.1 & 16 & 8.5 \\
\hline July & RE & 16.0 & 1.6 & 9 & 8.4 \\
& DI & 12.0 & 1.6 & 9 & 8.3 \\
& CE & 12.0 & 1.6 & 9 & 8.3 \\
& SG & 6.1 & 1.7 & 8 & 7.4 \\
\hline November & RE & 23.0 & 1.7 & 20 & 7.5 \\
& DI & 19.7 & 1.5 & 20 & 7.5 \\
& CE & 9.0 & 1.9 & 21 & 7.5 \\
& SG & 6.0 & 1.6 & 19 & 7.4 \\
\hline
\end{tabular}

Z: depth, Zeu: euphotic zone, T.: temperature, RE: Represa, DI: Dilfa, CE: Centro, SG: San Gregorio. 
A hundred and twenty-four phytoplanktonic taxa distributed in 10 Classes were identified (Table 2). Aulacoseira granulata (Ehrenb.) Simon., A. granulata var. angustissima (Muller) Simon., A. granulata var. angustissima f. spiralis (Muller) Simon., A. cf. ambigua (Grun.) Simon., A. cf. distans (Ehrenb.) Simon., Cryptomonas spp. and Synedra ulna (Nitzsch) Ehrenberg were always present. The length of the colonial filaments of Aulacoseira "granulata group" (A. granulata and A. cf. ambigua) varied widely ( 1 to 33 cells per filament), but 4 to 6 cells per filament was the most common length.

Phytoplankton abundance varied from 29 (autumn, CE) to $2129 \mathrm{ind} / \mathrm{ml}$ (summer, SG) (Fig. 2). Diatomophyceae was dominant during almost all the study period, being $A$. "granulata group" the most abundant taxa, replaced by $A$. cf. distans in November. Phytoflagellates, mainly represented by Cryptomonas spp., were the dominant group at SG in February, reaching $76 \%$ of the total abundance. Euchlorophyceae and Zygophyceae represented less than $8 \%$ of the phytoplankton abundance, while other Classes never exceeded $1 \%$.

The cluster analysis revealed three groups: one conformed by the stations performed during the cold months (May and July), excepting RE in May. The second comprissed SG, CE and DI in November and RE in May. A third group included RE and DI in February. CE and SG in February and RE in November did not join the above mentioned groups (Fig. 3).

\section{DISCUSSION}

Abiotic factors, as the mixing of the system and inorganic turbidity, influence plankton dynamic (Tundisi, 1990b). In our study, the maximum euphotic zone registered in summer and the minimum in autumn and winter (Table 1), could be related to variations in irradiance, turbidity and winds.

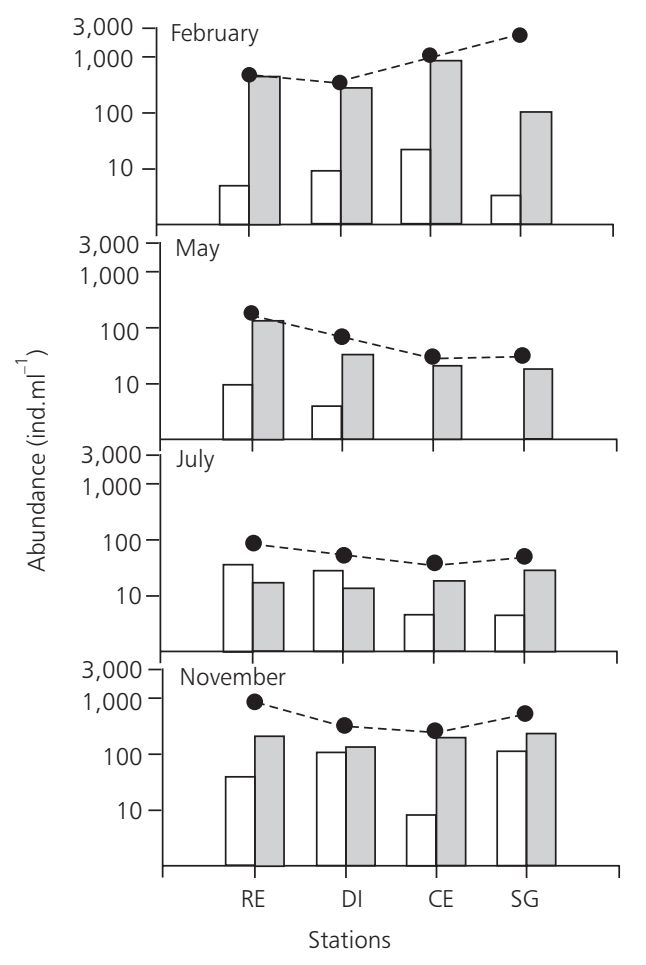

Fig. 2 - Abundance (individuals per milliliter) of total phytoplankton (solid circles), Aulacoseira spp. (dark bars) and other diatoms (white bars), for the four sampling stations at Rincón del Bonete reservoir. The y-axis is in logarithmic scale. Codes as in Fig. 1. 
TABLE 2

List of algal taxa found at Rincón del Bonete Reservoir.

\begin{tabular}{|c|c|c|}
\hline CHRYSOPHYCEAE & DINOPHYCEAE & EUGLENOPHYCEAE \\
\hline Dinobryon sertularia Ehrenberg & Peridinium $\mathrm{cf}$. wisconsinense Eddy & Euglena acus Ehrenberg \\
\hline Mallomonas spp. & Peridinium sp. 1 & Euglena cf. proxima Dangeard \\
\hline Synura sp. & EUCHLOROPHYCEAE & Euglena cf. variabilis Klebs \\
\hline CRYPTOPHYCEAE & Actinastrum cf. hantzschii Lagerheim & Peranema sp. \\
\hline Cryptomonas cf. brasiliensis Castro, Bic. \& Bic. & Ankistrodesmus bibraianus (Reinsch) Korsikov & Phacus tortus (Lemm.) Skvortzow \\
\hline Cryptomonas erosa Ehrenberg & Ankistrodesmus spp. & Phacus sp. 1 \\
\hline Cryptomonas marssonii Skuja & Botryococcus cf. braunii Kützing & Strombomonas sp. \\
\hline Cryptomonas pyrenoidifera Geitler & Coelastrum microporum Naegeli & Trachelomonas armata (Ehrenb.) Stein \\
\hline Cryptomonas spp. & Coelastrum cambricum Archer & Trachelomonas hispida (Perty) Stein \\
\hline CYANOPHYCEAE & Crucigenia spp. & Trachelomonas volvocinopsis Swir \\
\hline Anabaena cf. spiroides Klebahn & Chlamydomonas spp. & Trachelomonas sp. 1 \\
\hline Anabaena sp.1 & Dimorphococcus lunatus A. Braun & Trachelomonas sp. 2 \\
\hline Anabaena sp. 2 & Dictyosphaerium cf. pulchellum Wood & Trachelomonas spp. \\
\hline Anabaena sp. 3 & Eudorina elegans Ehrenberg & XANTOPHYCEAE \\
\hline Cylindrospermum sp. & Eudorina sp. 1 & Pseudostaurastrum sp. \\
\hline Lyngbya sp. 1 & Eutetramorus fottii (Hindak) Komárek & Tetraplektron sp. \\
\hline Lyngbya spp. & Kirchneriella obesa (W. West) Schmidle & ZYGOPHYCEAE \\
\hline Merismopedia glauca (Ehrenb.)Kützing & Micractinium pusillum Fresenius & Closterium aciculare T. West. \\
\hline Microcystis aeruginosa Kützing & Micractinium bornhemiense (Conrad) Korsikov & Closterium cf. acutum Brébisson \\
\hline Microcystis wesenbergii Komárek & Monoraphidium spp. & Closterium cf. gracile Brébisson \\
\hline Oscillatoria chlorina Kütz. ex Gomont & Oocystis sp. & Closterium kuetzingii Brébisson \\
\hline Oscillatoria limosa (Roth) Agardh & Pandorina morum (Muller) Bory & Closterium cf. pronum Brébisson \\
\hline Phormidium splendida Greville & Paradoxia multiseta Swirenk & Closterium sp. 1 \\
\hline Oscillatoria spp. & Platydorina caudata Kofoid & Closterium sp. 2 \\
\hline Pseudanabaena mucicola (Naum.H-.Pest.) Bourr. & Pediastrum biradiatum Meyen & Closterium spp. \\
\hline DIATOMOPHYCEAE & Pediastrum boryanum (Turpin) Meneghini & Cosmarium sp. 1 \\
\hline Aulacoseira cf. ambigua (Grun.) Simon. & Pediastrum duplex Meyen & Cosmarium sp. 2 \\
\hline Aulacoseira cf. distans (Ehrenb.) Simon. & Pediastrum simplex (Meyen) Lemmermann & Cosmarium sp. 3 \\
\hline Aulacoseira granulata (Ehrenb.) Simon. & Pediastrum tetras (Ehrenb.) Ralfs & Cosmarium spp. \\
\hline A. granulata var. angustissima (Muller) Simon. & Scenedesmus acuminatus (Lagerh.) Chodat & Desmidium bayleyi (Ralfs) De Bary \\
\hline A. gr.var. angustissima f. spiralis (Muller) Simon. & Scenedesmus denticulatus Lagerheim & Euastrum spp. \\
\hline Aulacoseira herzogii (Lemm.) Simon. & Scenedesmus cf. opoliensis Richter & Gonatozygon monotaenium De Bary \\
\hline Aulacoseira sp. 1 & Scenedesmus cf. quadricauda (Turpin) Bréb. & Gonatozygon sp. \\
\hline Cyclotella / Cyclostephanos sp. & Scenedesmus sp. 1 & Pleurotaenium sp. \\
\hline Eunotia spp. & Scenedesmus sp. 2 & Staurastrum gladiosum Turner \\
\hline Synedra ulna (Nitzsch) Ehrenberg & Scenedesmus spp. & Staurastrum manfeldtii Delponte \\
\hline Gomphonema sp. & Sorastrum sp. & Staurastrum sp. 1 \\
\hline Melosira varians Agardh & Sphaerocystis schroetheri Chodat & Staurastrum sp. 2 \\
\hline Nitzschia cf. acicularis (Kutz.) W. Sm. & Treubaria sp. & Staurastrum sp. 3 \\
\hline Nitzschia sp. & Volvox sp. & Staurastrum spp. \\
\hline Rhizosolenia longiseta Zach. & ULOTHRICOPHYCEAE & Staurodesmus spp. \\
\hline Surirella spp. & Oedogonium sp. & Mougeotia sp. \\
\hline Pennales (undetermined) & Planctonema lauterbornii Schmidle & Spirogyra sp. \\
\hline
\end{tabular}




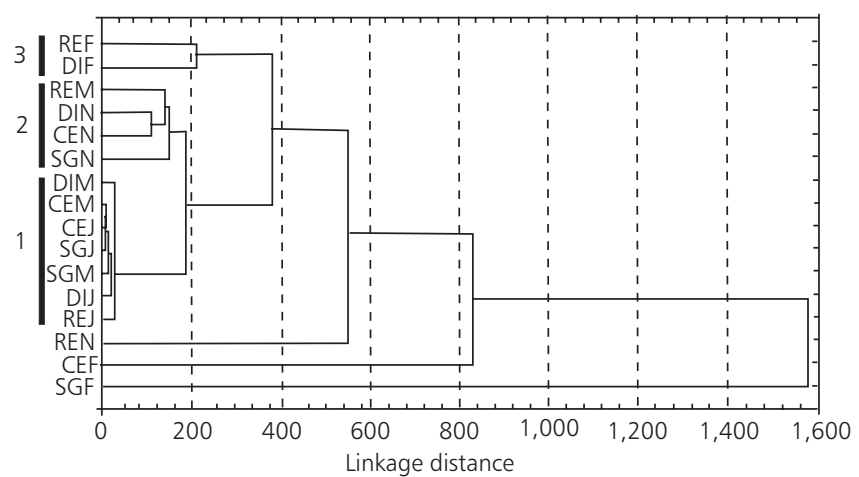

Fig. 3 - Cluster analysis based on species abundance, using euclidean distance and the UPGMA method. Codes as in Fig. 1.

In this polymictic system, water circulation usually involves the whole water column (Conde et al.,1994), a characteristic also present in most of the reservoirs in tropical South America (Tundisi, 1990a).

Fluctuation of phytoplankton abundance could be related to seasonal temperature variation and the depth of euphotic zone (Tundisi, 1990b). During cold months (May and July) low phytoplankton abundance coincides with low temperatures and reduced euphotic zone (Fig. 2). Moreover, turbidity seems to be not generated by phytoplankton, and the presence of inorganic suspension solids can be expected (Pintos et al., 1991; Conde, et al., 1994), with a negative effect on phytoplankton light availability.

Algal community were mainly dominated by Aulacoseira spp. (Diatomophyceae) (Table 2, Fig. 2) which presented a high frequency of filaments with 4 to 6 cells, a characteristic related to turbulent conditions (Davey, 1987). Aulacoseira is a Rstrategist widespread diatom, that can dominates in reservoirs under turbid conditions (Hutchinson, 1967; Reynolds, 1993). The dominance of Aulacoseira spp. found at Rincón del Bonete reservoir was also observed in Salto Grande polymictic reservoir (Quirós \& Luchini, 1982) and in the large rivers of La Plata River basin (O' Farrell \& Izaguirre, 1994).

The cluster analysis revealed spatial differences among sampling stations in spring and summer. The dominance of small phytoflagellates at SG in February, mainly represented by Crypto- monas spp. (Table 2) explained the location of this station in the cluster graphic representation (Fig. 3 ). Phytoplankton community was homogeneous during cold months, while differences between sampling stations were found in warmer ones, suggesting that sampling sites could be independent compartments. Further studies considering nutrients and physical factors in a more frequent sampling sequence are needed to provide a full description of the community.

Acknowledgments - We are very grateful to M. C. Calijuri (CRHEA, University of São Paulo) for the critical reading of the manuscript, to D. Conde (Faculty of Sciences, Montevideo) and O. Defeo (Fisheries National Institute of Uruguay) for the english corrections; to C. Odebrecht (University of Rio Grande do Sul) and R. Arocena (Faculty of Sciences, Montevideo) for suggestions. This work was supported by PNUD (Grant number URU 92-003).

\section{REFERENCES}

BAXTER, R. M., 1977, Environmental effects of dams and impoundments. Ann. Rev. Ecol. System, 8: 255-283.

BERÓN, L., 1990, Features of the limnological behavior of Salto Grande's reservoir (Argentina-Uruguay). Ecol. Model., 52: 87-102.

BOURRELLY, P., 1972, 1981, 1985, Les Algues d'Eau Douce: Initiation a la Systematique. Les Algues Verts, Les Algues Jaunes et Brunes, and Les Algues Bleues et Rouges, les Eugléniens, Peridiniens et Cryptomonadines. Paris, Ed. N. Boubée.

CALIJURI, M. C., 1988, Respostas Fisioecológicas da Comunidade Fitoplanctônica e Fatores Ecológicos em Ecossistemas com Diferentes Estágios de Eutrofização. Tese de Doutorado, Escola de Engenharia de São Carlos, Universidade de São Paulo, Brasil, 293p. 
CAMPO, H., 1991, Interacción entre el Ecosistema Monte Ripario y los Embalses. Cuenca del río Negro. Tesis de Maestría, PEDECIBA - Biología, Facultad de Ciencias, Universidad de la República, Uruguay, 121p.

CONDE, D., GORGA, J., DE LEÓN, R. \& FABIÁN, D., 1994, Informe de los Muestreos Limnológicos II-IV en el Embalse Gabriel Terra (Rincón del Bonete). Montevideo, Sección Limnología, Facultad de Ciencias, Universidad de la República, 60p.

DAVEY, M. C., 1987, Seasonal variation in the filament morphology of freshwater diatom Melosira granulata (Ehrenb.) Ralfs. Freshwat. Biol., 18: 5-16.

DE FILIPPO, R., 1987, Ciclo Sazonal do Fitoplâncton, Fatores Climáticos e Hidrológicos na Represa de Barra Bonita, São Paulo. Dissertação de Mestrado, PPGERN-DCB, Universidade Federal de São Carlos, 90p.

HASLE, G. R. \& FRYXELL, G. A., 1970, Diatoms: cleaning and mounting for light and electron microscopy. Trans. am. microsc. Soc., 89: 469-474.

HUTCHINSON, G. E., 1967, A Treatise on Limnology, v. 2. Introduction to Lake Biology and the Limnoplankton. New York, Wiley J. \& Sons, 1115p.

KÖLHER, J., 1994, Origin and succession of phytoplankton in a river-lake system (Spree, Germany). Hydrobiologia, 289: 73-83.

LEGENDRE, L. \& LEGENDRE, P., 1984, Ecologie numerique. 2. La strucutre des donnees ecologiques. Paris. Masson (ed.), 335p.

LUND, J. W. G., KIPLING, C. \& LE CREN, E. D., 1958, The inverted microscope method of estimating algal numbers and the statistical basis of estimations by counting. Hydrobiologia, 2: 143-170.

O'FARRELL, I. \& IZAGUIRRE, I., 1994, Phytoplankton ecology and limnology of the River Uruguay Lower Basin (Argentina). Arch. Hydrobiol. Suppl., 99: 155-179.
PINTOS, W., CONDE, D., DE LEON, R., CHALAR, G., FABIAN, D. \& DE LEON, L., 1991, Informes de los tres muestreos limnológicos realizados en los embalses del Río Negro. Montevideo, Sección Limnologia, Facultad de Ciencias, Universidad de la República, 22p.

QUIRÓS, R. \& LUCHINI, L., 1982, Características limnológicas del embalse de Salto Grande, III: Fitoplancton y su relación con parámetros ambientales. Rev. Asoc. Cs. Nat. Lit., 13: 49-66.

REYNOLDS, C. S., 1993, Scales of disturbance and their role in plankton ecology. Hydrobiologia, 249: 157-171.

ROSENBERG, D. M., BODALY, R. A. \& USHER, P. J., 1995, Environmental and social impacts of large scale hydroelectric development: who is listening? G. Environ. Chan., 5: 127-148.

TUNDISI, J. G., 1990a, Perspectives for ecological modelling of tropical and subtropical reservoirs in South America. Ecol. Model., 52: 7-20.

TUNDISI, J. G., 1990b, Distribuição espacial, seqüência temporal e ciclo sazonal do fitoplâncton em represas: fatores limitantes e controladores. Rev. Brasil. Biol., 50: $937-955$.

TUNDISI, J. G., 1994, A Systematic Approach to River/ Reservoir Research and Management, pp. 125-134. In: U.N.C.R.D. (ed.), Environmental and Social Dimensions of Reservoir Development and Management in the La Plata River Basin, Research Report Series no 4, Nagoya.

UTERMÖHL, H., 1958, Zur vervollkommung der quantitativen phytoplankton-methodik. Mitt. Int. Verein. Limnol., 9: 1-38. 